\title{
Path Analysis on The Biological and Social Life Course Factors Affecting Childs Speech and Language Development Delay
}

\author{
Merlita Indriasih 1,2), Harsono Salimo3), Eti Poncorini Pamungkasari4) \\ 1)Pratama Amanda Clinic, Yogyakarta \\ 2)Master Program in Public Health,Universitas Sebelas Maret \\ 3)Department of Pediatrics Dr.Moewardi Hospital, Surakarta \\ 4)Faculty of Medicine, Universitas Sebelas Maret
}

\begin{abstract}
Background: The development in children occurs once during the period of their life. The language ability is an indicator of all the development. The lack of stimulation can cause speech and language disorders and this disorder can persist. This study aimed to determine the effects of biological and social life course factors on delayed speech and language development.

Subjects and Method: This study was an observational analytic with cross-sectional approach, conducted in 25 integrated health posts (posyandu) located in Sleman Regency, Yogyakarta in March to April 2019. The total sample of 225 toddlers was chosen using fixed exposure sampling. The dependent variable was delayed speech and language development. The independent variables were income, employment, nutritional status, birth weight, history of toxoplasma, rubella, CMV and TORCH, history of infection, duration of gadget use, language, frequency of posyandu visit, and early childhood education (PAUD). Data collection on delayed speech and language development were measured by Denver II. The data were analyzed by path analysis.

Results: Speech and language delayed development was directly decreased with normal birth weight $(b=-2.19 ; 95 \% \mathrm{CI}=-3.58$ to $-0.79 ; \mathrm{p}=0.002)$, employed mother $(\mathrm{b}=-1.32 ; 95 \% \mathrm{CI}=-2.38$ to $-0.27 ; \mathrm{p}=0.013)$, good nutritional status $(\mathrm{b}=-2.14 ; 95 \% \mathrm{CI}=-3.37$ to $-0.91 ; \mathrm{p}=0.001)$, regularly attend integrated health post $(\mathrm{b}=-1.29 ; 95 \% \mathrm{CI}=-2.31$ to $-0.26 ; \mathrm{p}=0.013)$, mono language $(\mathrm{b}=$ $-1.02 ; 95 \% \mathrm{CI}=-1.99$ to $-0.04 ; \mathrm{p}=0.041)$, low duration of gadget use $(\mathrm{b}=-1.59 ; 95 \% \mathrm{CI}=0.23$ to 2.33; $\mathrm{p}=0.017$ ). Speech and language delayed development was directly increased with history of disease $(b=1.37 ; 95 \% \mathrm{CI}=0.34$ to $2.40 ; \mathrm{p}=0.009)$, and did not attend Pre-school $(\mathrm{b}=1.28 ; 95 \%$ $\mathrm{CI}=-2.65$ to $-0.53 ; \mathrm{p}=0.003)$. It was indirectly affected by number of children, income, and history of TORCH.

Conclusion: Delays in speech and language development are directly influenced by birth weight, infection history, employment, nutritional status, frequency to posyandu (integrated health posts), long usage of gadgets, PAUD (pre-school) and indirectly influenced by income and the number of children.
\end{abstract}

Keywords: the development of speech and language, the use of gadgets

\section{Correspondence}

Merlita Indriasih. Masters Program in Public Health, Universitas Sebelas Maret. Jl. Ir.Sutami 36A Surakarta 57126, Central Java, Indonesia. Email:merlitaindriasih@gmail.com. Mobile: 085641097941

\section{BACKGROUND}

Development is a change in terms of function. It can also be interpreted as the increase of skills (Soetjiningsih, 2013). Development in children occurs once during the life period and cannot be repeated (Moonik et al., 2015). Indonesia is one of the develop- ing countries with a number of children aged $\mathrm{o}$ to 17 a third of the population, and the age of $o$ to 5 years (toddlers) is a golden age for growth and development (Child Health Profile, 2015). Basic Health Research Indonesia, (2018) reported that the total index of development of children aged 36 to 
59 months (88.3\%) and for reading ability based on children's speaking and speaking ability (64.6\%) was still below Thailand (91.1\%) and (69.3\%) which in fact, both are still developing countries. According to Ministry of Health of the Republic of Indonesia (2016), children development is divided into four parts, namely cognitive, motoric, language and social-emotional development. Language development greatly influences cognitive development.

Language development can happen in a baby since pregnancy. Disorders of language development and speech are often found at an early age (Eadie et al., 2015). The number of children under five who experience delays in Indonesia is around 2.3\% to $24.5 \%$ while for school children it is found that the prevalence of delay is $5-18 \%$ (Suparmiati et al, 2013). Data shows the incidence of delays in the development of children in Dr. Sardjito Hospital in January to $\mathrm{Au}-$ gust 2015 was $58.5 \%$ and most of which occur are motor and speech delay (Permana, 2015). The accurate prevalence of language development and speech has not been reported regularly.

A study (Wijayanti et al., 2018) explains that factors that influence language development are seen from the social environment, parenting and language use. In addition to external factors, speech and language development is also influenced by several factors within a child such as the child's biological factors. Early detection of developments in Posyandu can be done for all healthy toddlers and the monitoring can be done on how often they participate (Ministry of Health, 2016). However, the number of posyandu in Sleman Regency does not eliminate the existence of underfive health problems such as nutritional problems (7.38\%) (prevalence of malnutrition) which significantly affects the development of toddlers. In 2017, in Sleman regency, there are approximately 74,561 toddlers. Of all toddlers in Sleman Regency, there are still some toddlers who have not yet visited health services to do SDI-DTK, which is found to be approximately 15,467 (4.8\%) children spread in the regency. This study aims to examine the biological and social factors of delays in the development of literature and language in Sleman Regency, Yogyakarta, Indonesia.

\section{SUBJECTS AND METHOD}

\section{Study Design}

This study was conducted using observational analytic with a cross-sectional approach. It was conducted in Sleman Regency, Yogyakarta Indonesia

\section{Population and Samples}

The population was toddlers aged 24 to 59 months at the Posyandu in the Sleman Regency region taken using random sampling. The sample of this study was 225 samples obtained from fixed exposure sampling.

\section{Study Variables}

The dependent variable was delayed speech and language development. The independent variables were family income, nutritional status, birth weight, number of children, maternal occupation, history of TOR$\mathrm{CH}$, history of infectious disease, length of playing gadgets, language, and frequency of posyandu visit.

\section{Operational Definition of Variables}

The delay in speech and language development was the delay in speech and language in children under the age of 24 to 59 months as measured by Denver II.

Family income was a family financial condition seen from monthly income. The occupational was the activities that can produce something in the form of money.

Toddler nutritional status was the comparison between body weight $(\mathrm{Kg})$ and age (month) under five according to Kep- 
menkes No. 1995/MENKES/SK/XII/2010 and by looking at the WHO Z-score table.

Birth weight was the weight of the baby at birth which was weighed immediately after birth. The number of children was the number of children owned in one family.

The history of TORCH disease during pregnancy was an infectious disease that has attacked during pregnancy such as: toxoplasma, rubella, CMV, and Herpes.

History of infectious diseases of infants under five is an infectious disease such as diarrhea (fluid defecation experienced by toddlers with a frequency of 3 times or more in one day), ARI (coughing or difficulty breathing) suffered by toddlers in the last 6 months. Mother language was a language used in the daily lives of families at home. The duration of the use of gadgets / devices is to use electronic devices in the form of smartphones, tablets, computers, and laptops. The data collection was done using a questionnaire. The measurement scale was a dichotomy.

The frequency of going to the posyan$\mathrm{du}$ was monthly visits to the posyandu every month. PAUD was formal or informal education for ages 2 to 6 years.

\section{Study Instrument}

The data of this study was obtained from a set of questionnaire.

\section{Analysis Data}

The data were analyzed using path analysis with the STATA program 13. Five steps of path analysis included model specifications, model identification, fit model estimation, and model specification.

\section{Research Ethics}

Research ethics include information on consent, anonymity, confidentiality, and ethical permission. Ethical permission from this study was published by the Research Commission on Medical Ethics of UNS No: 438 / uns27.6 / KEPK / 2019.

\section{RESULTS}

\section{Characteristics of Study Subjects}

Table 1 showed the results that most of toddlers in the study subjects were female, 121 subjects (53.78\%). The characteristics of the study subjects, namely in the mother's education, were senior high school graduates, 142 subjects $(63.10 \%)$ and most of them were aged $\leq 35$ years of 90 subjects $(60 \%)$.

Table 1. Sample characteristics

\begin{tabular}{lll}
\hline \multicolumn{1}{c}{ Variable } & n & \% \\
\hline Gender & & \\
Male & 104 & 46.22 \\
Female & 121 & 53.78 \\
Maternal Education & & \\
Do not graduate from PS & 1 & 0.40 \\
Pre-school graduate & 12 & 5.30 \\
Junior high school graduate & 42 & 18.70 \\
Senior High School graduate & 142 & 63.10 \\
Diploma III & 1 & 0.40 \\
Graduate program & 27 & 12.0 \\
Maternal Age & & \\
$\leq 35$ years & 135 & 60.00 \\
$>$ 35 years & 90 & 40.00 \\
\hline
\end{tabular}

\section{Univariate Analysis}

Univariate analysis in this study was to describe the data in general from each variable that the authors observed including: family income, nutritional status, birth weight, occupation, number of children, history of TORCH suffered by mother, history of toddler infection, length of time using gadgets, 
language, frequency to posyandu, and PAUD (pre-school). Table 2 showed that most children under five are from high income families, 166 (73.78\%). The nutritional status of toddlers was mostly good, 176 (78.22\%). Most infant birth weights

Table 2. Univariate analysis

\begin{tabular}{|c|c|c|}
\hline Variable & $\mathbf{n}$ & $\%$ \\
\hline \multicolumn{3}{|l|}{ Family Income } \\
\hline Low & 59 & 26.22 \\
\hline High & 166 & 73.78 \\
\hline Nutritional Status & 49 & 21.78 \\
\hline Poor & 176 & 78.22 \\
\hline \multicolumn{3}{|l|}{ Good } \\
\hline Birth weight (gram) & 42 & 18.67 \\
\hline$<2500$ & 183 & 81.33 \\
\hline \multicolumn{3}{|l|}{$\geq 2500$} \\
\hline Number of children & 133 & 59.11 \\
\hline$\leq 2$ & 92 & 40.89 \\
\hline \multicolumn{3}{|l|}{$>2$} \\
\hline Maternal occupation & 110 & 48.89 \\
\hline Working at home & 115 & 51.11 \\
\hline \multicolumn{3}{|l|}{ Working outside of home } \\
\hline TORCH history & 171 & 76.00 \\
\hline No history & 54 & 24.00 \\
\hline \multicolumn{3}{|l|}{ With history } \\
\hline \multicolumn{3}{|l|}{ Infection history } \\
\hline No & 159 & 70.67 \\
\hline Yes & 66 & 29.33 \\
\hline \multicolumn{3}{|c|}{ The duration of gadget usage } \\
\hline Less than an hour & 163 & 72.44 \\
\hline More than an hour & 62 & 27.56 \\
\hline \multicolumn{3}{|l|}{ Mother language } \\
\hline 1 language & 70 & 31.11 \\
\hline More than one language & 155 & 68.89 \\
\hline \multicolumn{3}{|c|}{ Frequency going to posyandu } \\
\hline Not every month & 52 & 23.11 \\
\hline Every month & 173 & 76.89 \\
\hline \multicolumn{3}{|l|}{ Pre School } \\
\hline No & 69 & 30.67 \\
\hline Yes & 156 & 69.33 \\
\hline
\end{tabular}

The history of infection (ARI / diarrhea) in toddlers shows that most of them have never had an infectious disease in which the infections in the form of ARI and diarrhea in the last 6 months, 159 (70.67\%). The duration of gadget usage for toddlers shows that most of them were less than 1 hour, 163 (72.44\%). Communication of the language used at home shows that most of them used 2 languages, namely Bahasa Indo- were normal ( $\geq 2500$ ) of 183 (81.33). Most of the mothers had an ideal number of children ( $\leq 2$ children), 133 (59.11\%), mothers had jobs outside the home of 115 (51.11\%). The majority of subjects had never suffered from TORCH's diseases 171 (76\%). nesian and regional language. Related to the frequency of going to posyandu shows that most of them visited posyandu each month, $173(76.89 \%)$ and the majority of them studied in PAUD, 156 (69.33\%).

\section{Path Analysis}

Table 3 showed the results of path analysis. The results of the path analysis describe the delay in speech and language influenced by birth weight, infection history, maternal oc- 
cupation, nutritional status, frequency to posyandu, duration of the use of gadgets and Pre School.

Toddlers' history of infection (ARI / diarrhea) increased the risk of speech delay by 1.37 units $(b=1.37 ; 95 \% \mathrm{CI}=0.34$ to 2.40; $\mathrm{p}=0.009)$. The use of gadgets for more than 1 hour increased the risk of delays in speaking and language of toddlers by 1.28 units $(b=-1.28 ; 95 \% \mathrm{CI}=0.23$ to 2.33 ; $\mathrm{p}=0.017)$.

Birth weight ( $\geq 2500 \mathrm{~g}$ ) reduced the risk of delays in speech and language in toddlers by 2.19 units $(\mathrm{b}=-2.19 ; 95 \% \mathrm{CI}=-$ 3.58 to-0.79; $\mathrm{p}=0.002)$. Good nutritional status of toddlers reduced the risk of delays in speech and language in toddlers by 2.14 units $(\mathrm{b}=-2.14 ; 95 \% \mathrm{CI}=-3.37$ to $-0.91 ; \mathrm{p}$ $=0.001)$.

That mothers who work outside of home reduced the risk of delays in speaking and language in toddlers by 1.32 units $(\mathrm{b}=-$ 1.32; $95 \% \mathrm{CI}=-2.38$ to -0.27 ; $\mathrm{p}=0.013$ ).

Frequency going to posyandu every month reduced the risk of delays in speaking and language in toddlers by 1.29 units $(\mathrm{b}=-1.29 ; 95 \% \mathrm{CI}=-2.31$ to $-0.26 ; \mathrm{p}=$ o.013). One language used at home decreased the risk of delays in speech and language in toddlers $(\mathrm{b}=-1.02 ; 95 \% \mathrm{CI}=-1.99$ to -0.04; $\mathrm{p}=0.041)$.

Pre-school reduced the risk of delays in speech and language by 1.59 units), PAUD ( $b=1.28 ; 95 \% \mathrm{CI}=-2.65$ to $-0.53 ; \mathrm{p}$ $=0.003)$. Family income was influenced by the number of children, nutritional status was influenced by family income and BBL, and infectious disease history of children under five was influenced by a history of TORCH.

Number of children which was more than 2 decreased the family income by 1.32 units ( $b=-1.32 ; 95 \% \mathrm{CI}=-1.94$ to $-0.69 ; \mathrm{p}$ $=<0.001)$. High family income increased the nutritional status by 1.58 units $(\mathrm{b}=$ $1.58 ; 95 \% \mathrm{CI}=0.76$ to $2.40 ; \mathrm{p}=<0.001)$.

Birth weight ( $\geq 2500 \mathrm{~g}$ ) improved good nutritional status by 2.60 units $(\mathrm{b}=$ 2.6; $95 \% \mathrm{CI}=1.73$ to $3.47 ; \mathrm{p}=<0.001$ ). The history of TORCH increased the likelihood of infection history by 1.11 units $(b=1.11$; $95 \% \mathrm{CI}=0.47$ to $1.75 ; \mathrm{p}=0.001$ ).

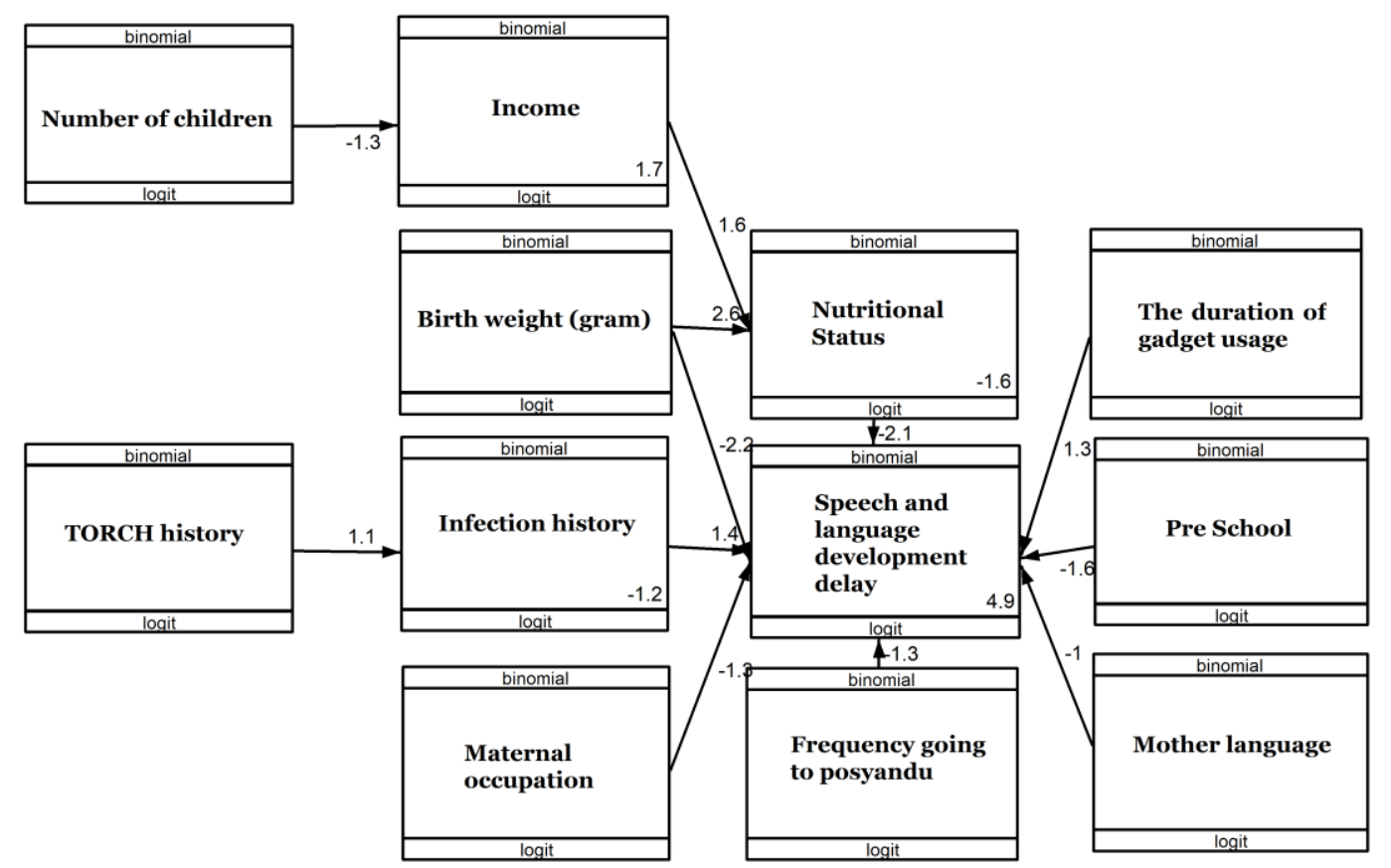

Figure 1. Path analysis model structure 
Journal of Maternal and Child Health (2019), 4(6): 11-22

https://doi.org/10.26911/thejmch.2019.04.06.02

Table 3. The results of path analysis

\begin{tabular}{|c|c|c|c|c|c|}
\hline \multirow[b]{2}{*}{ Dependent Variable } & \multirow[b]{2}{*}{ Independent Variable } & \multirow[b]{2}{*}{ b } & \multicolumn{2}{|c|}{$95 \% \mathrm{CI}$} & \multirow[b]{2}{*}{$\mathbf{p}$} \\
\hline & & & $\begin{array}{l}\text { Upper } \\
\text { Limit }\end{array}$ & $\begin{array}{l}\text { Lower } \\
\text { Limit }\end{array}$ & \\
\hline \multicolumn{6}{|l|}{ Direct Effect } \\
\hline \multirow{9}{*}{$\begin{array}{l}\text { Speech and language } \\
\text { development delay }\end{array}$} & Birth weight ( $\geq 2500 \mathrm{~g}$ ) & -2.19 & -3.58 & -0.79 & 0.002 \\
\hline & Infection history & 1.37 & 0.34 & 2.40 & 0.009 \\
\hline & $\begin{array}{l}\text { Occupation (working outside of } \\
\text { home) }\end{array}$ & -1.32 & -2.38 & -0.27 & 0.013 \\
\hline & Nutritional status (good) & -2.14 & -3.37 & -0.91 & 0.001 \\
\hline & $\begin{array}{l}\text { Frequency going to } \\
\text { Posyandu (every month) }\end{array}$ & -1.29 & -2.31 & -0.26 & 0.013 \\
\hline & PAUD/Pre school & -1.59 & -2.65 & -0.53 & 0.003 \\
\hline & $\begin{array}{l}\text { The duration of gadget usage ( }>1 \\
\text { hour) }\end{array}$ & -1.28 & 0.23 & 2.33 & 0.017 \\
\hline & language (one) & -1.02 & -1.99 & -0.04 & 0.041 \\
\hline & number of children $(\geq 2)$ & -1.32 & -1.94 & -0.69 & $<0.001$ \\
\hline \multicolumn{6}{|l|}{ Indirect Effect } \\
\hline Income & Income (high) & 1.58 & 0.76 & 2.40 & $<0.001$ \\
\hline Nutritional Status & Birth Weight ( $\geq 2500$ g) & 2.60 & 1.73 & 3.47 & $<0.001$ \\
\hline Nutritional Status & History of TORCH & 1.11 & 0.47 & 1.75 & 0.001 \\
\hline \multicolumn{6}{|l|}{ Infection history } \\
\hline N Observation: 225 & $\mathrm{p}<0.001$ & & & & \\
\hline $\begin{array}{l}\text { Log Likelihood: - } \\
486.729\end{array}$ & df: 57 & & & & \\
\hline
\end{tabular}

\section{DISCUSSION}

1. The Effect of Birth Weight on the Risk of Delays in the Development of Speech and Language in Toddlers

The results of the analysis showed the influence of birth weight on the risk of the speech and language delay. Normal birth weight could reduce the risk of delays in speech and language development.

Madigan et al. (2015), it was explained that one of the risk factors brought by a toddler that can influence speech and language development is birth weight. Underweight birth weight $(<2500$ g) can increase the risk of language development and speech of the toddler. Other studies explain similarly that one of the causes of delays in speech and language development in infants is low birth weight $(<2500 \mathrm{~g})$ (Safriana et al., 2017).

Stolt et al. (2014) explained the results that low birth weight could be a predictor of language and speech abilities in children. This can be sustainable with other developments not only can there be delays in speech and language development but also have an impact on widespread development delays (Paz et al., 2017).

Datar et al. (2009) explained that birth control with a low birth weight can be controlled through examination and monitoring during pregnancy so that the risk factors for low birth weight births can be handled as early as possible so as to minimize the developmental disturbances that occur. This control can be long-term in the life of a child who will continue to develop motorically, verbally and socially emotionally.

2. The Effect of Infection History on the Risk of Delays in the Development of Speech and Language in Toddlers

The results of the analysis showed that there was an influence between the history of infection and the risk of delays in speech 
and language. The presence of an infection history increased the risk of delays in speech and language.

The study that supports the results of this study is the study of Scharf et al. (2014), describing that continuous diarrheal diseases suffered by children can interfere with children's growth and development. According to Sajalia et al. (2018) the history of infection (ARI / diarrhea) is one of the causes of stunting which can result in child development disorders.

Infection that directly attacks the nervous system (zika, chikungunya, west Nile and other infections) can cause permanent or temporary disruption in the brain's nervous system. This infection can result in developmental disorders in children if the child experiences the infection (Mwesige et al., 2018). According to Barron and Hayden, (2016) children affected by infection will continue to experience malnutrition which can result in body weight that does not rise even tends to fall where if the weight decreases the child in the developmental period can not learn more because easily tired and not powerful. Age under five years is the golden age of children to grow and develop.

\section{The Effect of Employment on the Risk of Delays in the Development of Speech and Language in Tod- dlers}

The results of the analysis indicated a direct influence between the occupation of the mother and the risk of delays in speech and language. A study by Rahmawati et al. (2016) state that the working status of mothers who work part-time can better manage work and care for their children, so that the mother will be more sensitive to language development and interact with children so that children's language and speech skills are better. In the study, it was found that the occupation of the mothers were not fulltime and only worked 4 to 8 hours / day, so there was still time to interact with their children.

According to Poduval et al. (2009) mothers who work outside have great responsibility and independence in educating and managing their time to be able to act as mothers for their children. Working mothers will feel complete roles as women because they can be financially independent and can play a role as a mother. Meanwhile, according to Malmberg et al. (2015) sensitivity between mothers and fathers in caring for children will affect children's sensitivity to their cognitive and language abilities. Therefore, the development of speech and language of a good child is the task/duty of the parents.

\section{The Effect of Nutritional Status of Toddlers on the Risk of Delays in the Development of Speech and La- nguage in Toddlers}

The results of the analysis showed that there was a significant influence on the risk of delay in speech and language development. This result is in line with Vaivada et al. (2017) that the development of speech and language of toddlers was influenced by their nutritional status where the way of giving and eating patterns related to oral toddlers will affect the way toddlers eat their food. The food given can affect nutritional status and influence the development of speech and language of the toddler.

The fulfillment of food nutrition obtained by toddlers (<5 years) has an important role for the development process of toddlers. If the fulfillment of nutrition was poor, it could result poor nutritional status as well so that these toddlers would experience potential setbacks in their development (Hurley et al., 2016). According to Prado et al. (2014), the brain development of a child starts during pregnancy. During pregnancy the need for macronutrient and 
micronutrient intake must be fulfilled.

\section{The Effect of Frequency of going to Posyandu on the Risk of Delays in Speech and Language Develop- ment in Toddlers}

A study by Lolita et al. (2019) explained that the existence and participation of posyandu influences the development of children under five. According to Niccols et al. (2012), integrated service programs regarding pregnancy, child care and child problems greatly influence the monitoring of children's growth and development and improve parental behavior towards participation in this integrated service program. One of the activities at the posyandu is conducting early detection of toddler development problems. Toddlers will be monitored and detected early if the toddler comes regularly to the posyandu every month (Asthiningsih and Muflihatin, 2018).

\section{The Effect of PAUD on the Risk of Delays in the Development of Spe- ech and Language in Toddlers}

The results of the analysis showed that there was a direct influence between Pre-school participation and the risk of delays in speech and language development where the results showed that the participation reduced the risk of language and speech delay. A study that supports this was conducted by Brodin and Renblad, (2019) explaining that the existence of schools that are attended by children under five (preschool) can improve children's speaking and speaking skills. The preschool learning system is made as comfortable as possible so that the child is comfortable to learn.

Activities in the preschool invite children to apply what is obtained and can practice directly communication with teachers and their friends (Brebner et al., 2017). PAUD educators teach the meaning of the vocabulary they learn the proper grammar when speaking (Lonigan et al., 2017).

\section{The Effect of the duration of Gad- gets Usage on the Risk of Delays in the Development of Speech and Language in Toddlers}

The results of the analysis showed a direct influence between the length of time the gadget is used to the risk of delays in speech and language. The results of this study are in line with the result of Tan et al. (2019) explaining that the influence of gadgets given more than 1 hour to toddlers influences the delay in talking to toddlers. According to Verma et al. (2018) the negative impact of using gadgets that are too long for toddlers ( 2 years) can affect the cognitive development of the child.

Using gadgets that are too long in children under 6 years could increase the likelihood of delays in speech and language due to lack of interaction to hone vocabulary, speaking and social skills (Kuta, 2017). The influence of gadgets has positive and negative sides for toddlers, if managed properly in toddlers they can cause a developmental delay, namely development of speech and language.

\section{The Effect of the Language used at home on the Risk of Delays in the Development of Speech and La- nguage in Toddlers}

The results of the analysis showed that there was a direct influence between the language used at home and the risk of delays in speech and language in toddlers.

Festman's study (2018) explains that one language heard at home is more likely to improve children's speech and language understanding. Altman et al. (2017) explain that the way of learning between monolanguage and bilingual has the same pattern. The language used at home that is predominant in language should be taught first so that the child will be easy to understand and the speech will be well trained (Stoop, 2017). According to Jafari et al. 
(2015), it is explained that proper bilingual use of children will improve children's cognitive development so that the use of language in children should be adapted to the abilities of each child.

\section{The Effect of Family Income on the Risk of Delay in the Develop- ment of Speech and Language in Toddlers through the number of children}

The results of the analysis explained the influence of family income on the delay in speech and language development through the number of children. The results of this study are supported by the results of previous studies by Lolita et al. (2019) stating that one of the factors that influences the development of children under five (2 to 5 years) is family income.

Schwab et al. (2018) describe the differences between high and low socioeconomic parents where low socio-economic families show less vocabulary, language. Parental income plays a role in providing facilities that play a role in early childhood development (Urk et al., 2018).

Based on the results of these studies, it was found that biological and social factors influence the risk of delays in speech and language in infants both directly and indirectly.

\section{AUTHOR CONTRIBUTION}

Merlita Indriasih formulated the study problems, designed the conceptual frameworks, collected data and processed the data; Harsono Salimo examined the results and discussion; Eti Poncorini checked the data analysis.

\section{FUNDING AND SPONSORSHIP}

This study used the authors' independent costs.

\section{ACKNOWLEDGEMENT}

The author thanked the public health centers and integrated service posts cadres who helped her with the study. She also thanked the participating mothers who were willing to become respondents.

\section{CONFLICT OF INTEREST}

There is no conflict of interest in this study.

\section{REFERENCE}

Altman C, Goldstein T, Armon LS (2017). Quantitative and qualitative differences in the lexical knowledge of monolingual and bilingual children on the litmus-clt task.Clinical linguistics and phonetics. 31(11-12):931-954.http://doi.org/10.108o/02699206.2017.1312533.

Asthiningsih NWW, Muflihatin SK (2018). Deteksi dini perkembangan balita dengan metode DDST II di posyandu wilayah kerja Puskesmas Juanda Samarinda (Early Detection of Development of Toddlers with DDST II Method in Posyandu in Juanda Health Center Samarinda Working Area). Jurnal Endurance. 3(2): 367.http://doi.org/10.22216/jen.v3i2.3149.

Barron I, Hayden, TA (2016). Essentials of infection prevention in the pediatric population. International Journal of Pediatrics and Adolescent Medicine. 3(4): 143-152. doi: 10.1016/j.ijpam.2016.10.002.

Brebner C, Stacie A, Clarie M(2017). Facilitating children's speech, language and communication development: An exploration of an embedded, service-based professional development program. Child Language Teaching and Therapy. 33(3): 223-240. doi: 10.1177/o265659017702205 .

Brodin J, Renblad K (2019). Improvement of preschool children's speech and language skills. Early Child Development 
and Care. doi: 10.1080/03004430.2018.1564917.

Datar A, Jacknowitz A (2009). Birth weight effects on children's mental, motor, and physical development: Evidence from twins data. Maternal and Child Health Journal. 13(6): 780-794. doi: 10.1007/s10995-009-0461-6.

Eadie P, Angela M, Obioha CU, Kyriaki TE, Melissa W, Sheena R (2015). Speech sound disorder at 4 years: Prevalence, comorbidities, and predictors in a community cohort of children. Developmental Medicine and Child Neurology, 57(6): 578-584. doi: 10.1111/dmcn.12635 .

Festman J (2018). Vocabulary Gains of Mono- and Multilingual Learners in a Linguistically Diverse Setting: Results From a German-English Intervention With Inclusion of Home Languages.Frontiers in Communication. 3(0): 115. doi: 10.3389/fcomm.2018.00026.

Hurley KM, Yousafzai AK, Lopez F (2016). Early Child Development and Nutrition: A Review of the Bene fi ts and Challenges of. American Society for Nutrition.7(o): 357-363. doi: 10.3945/an.115.010363.by.

Jafari Z, Esmaili M, Toufan (2015). Bilingual proficiency and cognitive reserve in Persian-English bilingual older adults.Aging Clinical and Experimental Research. 27(3): 351-357. doi: 10.1007/s40520-014-0288-x.

Ministry of Health RI (2016). Pedoman Pelaksanaan Stimulasi, Deteksi dan Intervensi Dini Tumbuh Kembang Anak (Guidelines for the Implementation of Stimulation, Detection and Early Intervention of Child Growth). Summary for Policymakers. o(o):1-30. doi: 10.1017/CBO9781107415324.004.

Kuta C (2017). The Negative Impact of Excessive Screen Time on Language Development in Children Under 6 Years-
Old. Pediatric and Family Health Providers. Available at: https://scholarworks.umass.edu/nursing_dnp_capsto ne/91.

Lolita, Dewi YLR, Murti B (2019). Multilevel Analysis on the Contextual Effect of the Integrated Health Post Activity on Development of Children Under Five in Kubu Raya, West Kalimantan. 4(4): 222-229.

Lonigan CJ, Milburn T.F (2017). Identifying the Dimensionality of Oral Language Skills of Children With Typical Development in Preschool Through Fifth Grade.Journal of Speech, Language, and Hearing Research. 60(8): 2185-2198. doi: 10.1044/2017_jslhr-l-15-0402.

Madigan S, Mark W, Anre P, Dillon B (2014). Birth weight variability and language development: Risk, resilience, and responsive parenting. Journal of Pediatric Psychology.40(9): 869-877. doi: 10.1093/jpepsy/jsvo56.

Malmberg LE, Lewis S, West E, Murray E, Syla K, Stein A (2015).The influence of mother and father sensitivity in the first year of life on children's cognitive outcomes at $18-36$ months. Child:care, health and development. 42(1): 1-7. doi: 10.1111/cch.12294.

Moonik, Hesti, Roky (2015). Faktor-faktor yang mempengaruhi keterlambatan perkembangan anak taman kanak-kanak 2 (Factors that affect the delay in the development of kindergarten children 2). Jurnal e-Clinic. 3(0). Available at: https://ejournal.unsrat.ac.id/index.php /eclinic/article/view/6752/6276.

Mwesige AK, Abdul HM, Krister K, Sharon L, Julius JL (2018). Emerging viral infections in Sub-Saharan Africa and the developing nervous system: A mini review. Frontiers in Neurology. 9(0): 18. doi: 10.3389/fneur.2018.00082.

Niccols A, Milligan K, Sword W, Thabane L, Henderson J, Smith A, Sword W, Thabane LJ (2012). Integrated prog- 
rams for mothers with substance abuse issues and their children: A systematic. Harm Reduction Journal. 9(14): 1-11. https://doi.org/10.1186/14777517914.

Paz OO, Hanna M, Marian JJ, ineke Jm, Stefan VDS (2017). The link between motor and cognitive development in children born preterm and/or with low birth weight: A review of current evidence. Neuroscience and Biobehavioral Reviews.80(o): 382-393.doi: 10.1016/j.neubiorev.2017.06.009.

Permana A (2015). Hubungan antara prematuritas dengan perkembangan anak 2-3 tahun di RSUP DR. Sardjito (The relationship between prematurity and the development of children 2-3 years in the hospital Dr. Sardjito). Universitas Gadjah Mada. Available at: http://etd.repository.ugm.ac.id/index.php? $\bmod =\mathrm{p}$ enelitian_detail\&sub=PenelitianDetail \&act $=$ view\&typ $=$ html\&buku_id $=94282$ \&obyek_id=4.

Poduval J, Poduval M (2009).Working Mothers: how much working, how much mothers, and where is the womanhood? Mens Sana Monographs. 7(1): 63. doi: 10.4103/0973-1229.41799.

Prado EL, Dewey KG (2014). Nutrition and brain development in early life. Nutrition Reviews. 72(4): 67-284. doi: 10.1111/nure.12102.

Profile of Indonesian Children (2015). Profil anak indonesia (profile of indonesian children). Jakarta: Kementerian Pemberdayaan Perempuan dan Perlindungan Anak.

Rahmawati NA, Yudianto S, Munif S (2016) Status pekerjaan ibu sebagai prediktor kemampuan bahasa lisan anak usia 4-5 tahun (The Profile of Indonesian Children Job Status of Mothers As Predictors of Oral Language Ability for Children 45 Years Old). Universitas Sebelas Maret. Available at:http://www.jurnal.fkip.uns.ac.id/index.php/paud/article/view/85 61.
Basic Health Research (2018). Hasil utama riset kesehatan dasar, Kementrian Kesehatan Republik Indonesia (Main results of basic health research, Ministry of Health of the Republic of Indonesia). Jakarta: Ministry of Health RI.

Safriana L, Salimo H, Dewi YLR (2017). Biopsychosocial factors, life course perspective, and their influences on language development in children. Journal of Maternal and Child Health. 02(03): 245-256. doi: 10.26911/thejmch.2017.02.03.06.

Sajalia H, Dewi YLR, Murti B (2018). Life Course epidemiology on the determinants of stunting in children under five in East Lombok, West Nusa Tenggara. Journal of Maternal and Child Health. 03(04):242-251. doi: 10.26911/thejmch.2018.03.04.01.

Scharf R J, Deboer MD, Guerrant RL (2014). Recent advances in understanding the long-term sequelae of childhood infectious diarrhea. Current Infectious Disease Reports.16(6): 1-11. doi: 10.1007/s11908-014-0408-y.

Schwab JF, Lew WC (2018). Speech.Wiley Interdiscip revolution cognitive science. 7(4): 264-275. doi: 10.1002/wcs.1393.

Soetjiningsih (2013). Konsep dasar tumbuh kembangan anak (The basic concept of children development). Jakarta: EGC.

Stolt S, Korja J, Matomaki H, Lapinleimu L, Haataja L(2014). Early relations between language development and the quality of mother-child interaction in very-low-birth-weight children. Early Human Development. 90(5): 219-225. doi:10.1016/j.earlhumdev.2014.02.007.

Stoop C (2017).Children's rights to mothertongue education in a multilingual world: A Comparative Analysis between South Africa and Germany. Journal Elektroniese Regsblad. doi: 10.17159/1727-3781/2017/v20ioa820.

Suparmiati A, Ismail DM (2013). Hubungan ibu bekerja dengan keterlam- 
batan bicara pada anak (The relationship between working mothers and the delays in speech to children).Sari Pediatri. 14(5): 288-291. Available at: http://saripediatri.idai.or.id/pdfile/145-4.pdf.

Tan S, Irawan M, Wisnumurti DA (2019). Paediatrica Indonesiana. Pediatrica Indonesia. 52(5): 284-288. http://dx.doi.org/10.14238/pi59.2.2019.55-62.

Urke HB, Contreras M, Matanda, DJ (2018). The influence of maternal and household resources, and parental psychosocial child stimulation on early childhood development: A cross-sectional study of children 36-59 months in Honduras. International Journal of Environmental Research and Public Health. 15(5). doi: 10.3390/ijerph15050926.
Vaivada T, Gaffey MF, Bhutta ZA (2017). Promoting Early Child Development With Interventions in Health and Nutrition: A Systematic Review. Pediatrics. 140 (2). doi: 10.1542/peds.2016-4308.

Verma S, Suman N, Verma P (2018). Effect of electronic gadgets on cognitive milestones of children below 2 years of age. Iaim. 5(6): 52-54.

Wijayanti A, Wekadigunawan C, Murti B. (2018). The Effect of Parenting Style, Bilingual School, Social Environment, on Speech and Language Development in Preschool Children in Surakarta, Central Java. Journal of Maternal and Child Health. 03(03): 184-196. doi: 10.26911/thejmch.2018.03.03.03. 